\title{
Nuclear Abnormalities in Erythrocytes of Frogs from Wetlands and Croplands of Western Ghats Indicate Environmental Contaminations
}

\author{
Shreyas Raghunath ${ }^{1}$, Chethankumar Masaruru Veerabhadrappa ${ }^{1}$, Krishna Kulkarni ${ }^{1}$, Santosh Kumar Hulikal Shivashankara ${ }^{2}$, \\ Sannanegunda Venkatarama Bhatta Krishnamurthy ${ }^{1}$
}

\author{
${ }^{1}$ Department of Environmental Science, Kuvempu University, Shimoga Dist. Karnataka, India \\ ${ }^{2}$ Department of Biotechnology, Kuvempu University, Shimoga Dist. Karnataka, India
}

\section{ABSTRACT}

Anuran amphibians are the biological models to assess the influence of environmental contamination. We conducted nuclear abnormality assessment and micronuclei test in erythrocytes of frogs to identify an early influence of environmental contaminations. In Western Ghats of India, farmers use different agrochemicals and obviously, the amphibian habitat is contaminated with combinations of many residues. Many frog species use these agro-ecosystem for breeding and to complete early life stage. In the present study, we used Indian skipper frog (Euphlyctis cyanophlyctis (Anura: Ranidae)), a common inhabitant of water bodies in agro-ecosystems of Western Ghats for the assay. We collected the adult frogs from three different habitats; a) the rice paddy fields contaminated with agrochemicals, b) uncontaminated marsh and c) a shallow water pool. We recorded micronucleus, blebbed, lobed, kidney bean shaped nucleus and nucleus with notches in erythrocytes of these frogs. These nuclear abnormalities in erythrocytes are quantified. The incidences of occurrence of micronucleus ranged from 0 to 8 in 1000 analysed cells. More than $80 \%$ of the frogs living in agro-chemical contaminated site showed these abnormalities. The appearance of nuclear abnormalities indicates that the frogs are affected by agro-chemicals.

Keywords: Agro-chemicals, Euphlyctis cyanophlyctis, micronucleus, nuclear abnormalities, Western Ghats-India

\section{INTRODUCTION}

Agrochemicals are widely used in croplands to improve the crop yield. Indiscriminate applications of agrochemicals have increased the loss of habitat quality and toxicity to non-target organisms including amphibians $[1,2]$. However, many species of amphibians are able to persist in agriculture landscape [1]. Amphibians have been regarded as bioindicators on the basis of their biological uniqueness (bimodal life, poikilothermic, cutaneous respiration), and sensitivity to environmental changes and quality $[1,3-6]$. Amphibian populations are declining due to various factors and the effects of environmental contamination are of particular concern [7]. Western Ghats of India are known for their rich and diverse amphibian species [8-10]. Few toxicological studies carried out on the frogs of Western Ghats

\section{*Corresponding author:}

Sannanegunda Venkatarama Bhatta Krishnamurthy

Department of Environmental Science, Kuvempu University

Jnana Sahyadri, Shankaraghatta, Shimoga Dist. Karnataka, India 577451

E mail: svkrishnamurthy@gmail.com revealed changes in growth and development of frogs, morphological deformities and population decline in agro-ecosystems [11 - 15]. Agriculture terrains of Western Ghats comprise many small pieces of lands, each with different crop system and management practices, and owned by different farmers. Farmers use different agrochemicals and as a result, the terrain and the habitat gets contaminated with a mixture of agrochemicals [15]. In the study area, farmers use chlorpyrifos, quinalphos, monocrotophos (organophosphate pesticides), copper oxychloride, carbendazim, Bordeaux mixture (fungicides) and nitro-phosphate and potash (NPK) and other agro-chemicals for various crops. Gurushankara [16] explained the cytological and biochemical effect of organophosphate pesticides on frogs Limnonectus limnocharis of the same study region, while Gurushankara

\section{How to cite:}

Raghunath S, Veerabhadrappa CM, Kulkarni K, Shivashankara SKH, Krishnamurthy SVB (2017) Nuclear Abnormalities in Erythrocytes of Frogs from Wetlands and Croplands of Western Ghats Indicate Environmental Contaminations. J. Trop. Life. Science 7 (3): $208-212$. 
et al. [11] and Patel et al. [13] have explained the morphological abnormalities of these frogs living in highly contaminated rice-paddy agro-ecosystem. However, there is no information is available on such abnormalities in Euphlyctis cyanophlyctis, commonly inhabited in the same environment.

Assessment of biological effects on animal species is frequently employed to monitor contaminations [5]. The use of sensor organisms reveals the status of the dynamic scenario of environmental contamination and their biological effect [4]. Fluctuations in population attributes, deviation in their biological process, and nuclear and genetic abnormalities in particular have been considered as in indication of environmental contamination of toxicant in their habitats $[17,18,19]$. Therefore, frogs and toad are studied for various biomarkers of effects of xenobiotics and toxicants $[4,19]$. In this context, the present study is made with nuclear abnormality in RBCs of a frog (Euphlyctis cyanophlyctis, Anura: Ranidae) as a tool to understand the effect of agro-chemical contamination and associated genotoxic effect. Further, biomarker analysis is also used to assess the health status of frogs [20] and it is also used to evaluate the genetic damage resulting from exposure to environmental contaminants [21]. Genotoxicity assay was used in many studies as a biomarker to assess the environmental pollution [20, 22, 23]. The E. cyanophlyctis is an aquatic frog listed under least concerned (LC) in the International Union for Conservation of Nature (IUCN) red list. This frog generally occurs in shallow water bodies and are threatened by agrochemical contamination [24].

\section{MATERIALS AND METHODS}

We collected Frogs from three different sites located in Shimoga District of Karnataka State. The first site (Bidarakatte pond, Shankaraghatta, Loc: N $13^{\circ} 43^{\prime} 38^{\prime \prime}$; E $75^{\circ} 37^{\prime} 55^{\prime \prime}$, altitude: $640 \mathrm{~m}$ above sea level (asl)), is a perennial pond surrounded by rice paddy fields where farmer intensively use agro-chemicals. The second site is a shallow marsh (Loc: $\mathrm{N} 13^{\circ} 42^{\prime} 33.3^{\prime \prime}$; E $75^{\circ} 38^{\prime} 17.9^{\prime \prime}$ altitude: $620 \mathrm{~m}$ asl) amidst the large fish tanks located in the state fish farm and the third site (Loc: $\mathrm{N} 13^{\circ} 44^{\prime}$ 04.5"; E $75^{\circ} 38^{\prime} 1.0^{\prime \prime}$, altitude: $651 \mathrm{~m}$ asl) is an artificial, small and shallow tank located in the Kuvempu University campus. Site 1 had water spread over an area of $1.55 \mathrm{ha}$, in its total surrounding drainage area of $\approx$ 27.583 ha. The drainage area of site 1 includes 3.304 ha of Areca orchards, 22.734 ha of rice paddy cropland and a small portion of uncultivated land. Farmers use syn- thetic fertilizers (NPK, Muratte Potash, Urea) fungicides and pesticides (quinolphos, monocrotophos, malathion) in surrounding farmlands. The site 2 has total drainage area of $\approx 48.953$ ha and it has no significant sources of chemical contamination except human activities associated with fish seed/fry rearing. The earlier work of Hegde [25] have revealed that contaminant concentrations in these sites ranged between 0.15 and $0.45 \mathrm{ppm}$ as total residues of pesticides per $\mathrm{kg}$ dry weight of soil. Site 3 is totally uncontaminated area surrounded by secondary growth of vegetation in University campus. From January to March 2015, we collected 31 adult frogs of $E$. cyanophlyctis from these sites using a sweep net. Immediately after the collection, we measured the lengths of the frogs using digital calipers (Tresna); the weights of frogs were taken on weighing scale (model: AMW-100 V 2.0, digital pocket scale), and the sex was recorded (12 males and 19 females). The average SnoutVent Length and Body weight of these frogs are $32.85 \pm$ $4.078 \mathrm{~mm}$ and $3.5 \pm 1.13 \mathrm{~g}$ respectively. Frogs were transported to laboratory using a large container with habitat water.

In laboratory, we anesthetized frogs and then we blood by puncturing the heart. We prepared two peripheral blood smears for each sampled specimen on clean glass slides, fixed with methanol for ten minutes and then dyed with Giemsa stain $(10 \% \mathrm{v} / \mathrm{v})$. We viewed the slides under Olympus CX21FS1 Optic Microscope (40x magnification). We counted a total of random 1000 erythrocytes per slide. We determined the Micronucleus (MN) following the method explained by Lajmanovich et al., [26] and we identified other nuclear abnormalities, viz., Kidney Shaped Nuclei (KS), Lobed Nuclei (LB), and Notched Nuclei (NT) following Carrasco et al., [27]. We determined blebbed nuclei (BL) according to the criteria adopted by Strunjak-Perovic et al., [28]. We compared incidences of nuclear abnormalities in frogs from the three different sites by taking the mean values. Further data are fitted to non-parameteric Kruskal-Wallis test to identify any similarity in nuclear abnormality between the sites. A value of $\mathrm{p}<0.05$ was considered as significant. In order to check the occurrence of similar incidence of $\mathrm{MN}$ in erythrocytes in different sampling sites, $\chi^{2}$ test was used and $p<0.05$ was considered as significant.

\section{RESULTS AND DISCUSSION}

The normal mature erythrocyte of E. cyanophlyctis is an oblong-oval shape with a centric nucleus (Figure 1a). In the present study, we observed five major nuclear 

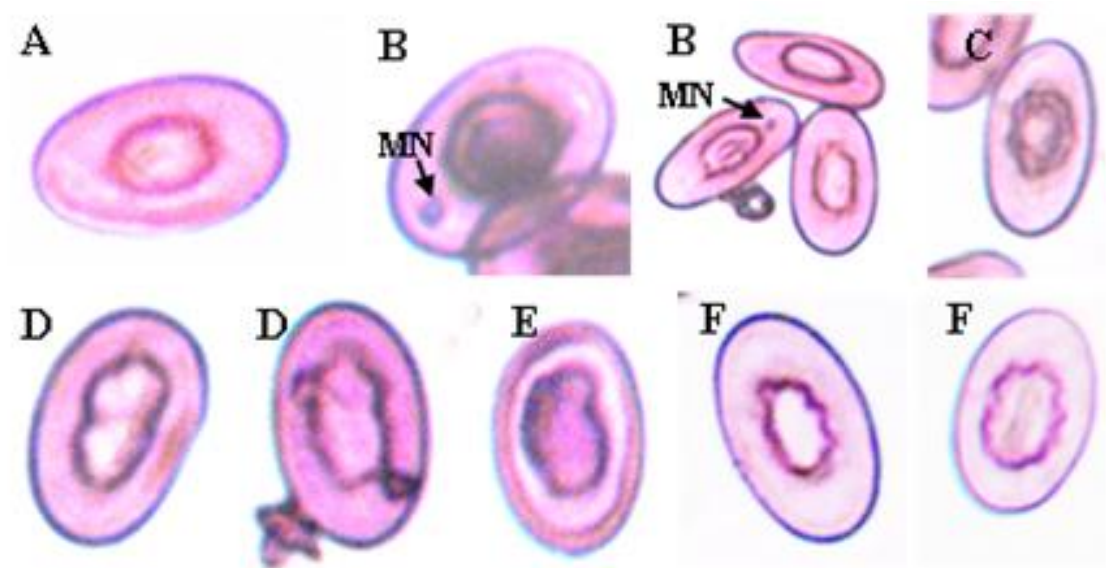

Figure 1. Nuclear abnormalities in erythrocytes of E. cyanophlyctis. Normal erythrocyte (a), Micronucleus (MN) (b), blebbed nucleus (c), lobed nucleus (d), kidney bean shaped nucleus (e) and nucleus with notch (f)

Table 1. Nuclear abnormality assays in erythrocytes of E. cyanophlyctis.

\begin{tabular}{|c|c|c|c|c|}
\hline Abnormality & Data & Site 1 & Site 2 & Site 3 \\
\hline \multirow[t]{4}{*}{$\mathrm{MN}$} & Upper extreme $^{a}$ & 8 & 1 & 1 \\
\hline & Lower extreme $^{b}$ & 0 & 0 & 0 \\
\hline & Mean ( \pm S.E. $)$ & $2.13 \pm 0.448$ & $0.28 \pm 0.135$ & $0.30 \pm 0.132$ \\
\hline & No of animals & $11 / 12$ & $3 / 9$ & $4 / 6$ \\
\hline \multirow[t]{4}{*}{$\mathrm{BN}$} & Upper extreme $^{a}$ & 38 & 119 & 127 \\
\hline & Lower extreme $^{b}$ & 0 & 0 & 0 \\
\hline & Mean $( \pm$ S.E. $)$ & $0.83 \pm 0.180$ & $33.00 \pm 8.550$ & $81.33 \pm 10.310$ \\
\hline & No of animals & $12 / 12$ & $9 / 9$ & $6 / 6$ \\
\hline \multirow[t]{4}{*}{$\mathrm{LN}$} & Upper extreme $^{a}$ & 24 & 2 & 7 \\
\hline & Lower extreme ${ }^{b}$ & 0 & 0 & 0 \\
\hline & Mean ( \pm S.E. $)$ & $2.91 \pm 1.007$ & $0.17 \pm 0.121$ & $2.00 \pm 0.707$ \\
\hline & No of animals & $12 / 12$ & $1 / 9$ & $5 / 6$ \\
\hline \multirow[t]{4}{*}{ KSN } & Upper extreme $^{a}$ & 3 & 1 & 1 \\
\hline & Lower extreme $^{b}$ & 0 & 0 & 0 \\
\hline & Mean $( \pm$ S.E. $)$ & $0.16 \pm 2.134$ & $0.11 \pm 0.076$ & $0.080 \pm 0.030$ \\
\hline & No of animals & $11 / 12$ & $2 / 9$ & $1 / 6$ \\
\hline \multirow[t]{4}{*}{$\mathrm{NN}$} & Upper extreme $^{a}$ & 3 & 9 & 22 \\
\hline & Lower extreme $^{b}$ & 0 & 0 & 0 \\
\hline & Mean $( \pm$ S.E. $)$ & $1.83 \pm 0.383$ & $3.44 \pm 0.926$ & $9.58 \pm 2.330$ \\
\hline & No of animals & $12 / 12$ & $7 / 9$ & $6 / 6$ \\
\hline
\end{tabular}

${ }^{a}$ Maximum incidence in a single animal recorded per 1000 erythrocytes

${ }^{\mathrm{b}}$ Minimum incidence in a single animal recorded per 1000 erythrocytes

SE denotes the standard error, $\mathrm{MN}=$ micronuclei, $\mathrm{BN}=$ blebbed, $\mathrm{LN}=$ lobed, $\mathrm{KSN}=$ kidney shaped, $\mathrm{NN}=$ notched

abnormalities viz., presence of micronucleus ( $\mathrm{MN}$ - Figure $1 \mathrm{~b}$ ), blebbed nucleus (BN - Figure 1c), lobed nucleus (LN - Figure 1d), kidney bean shaped nucleus $(\mathrm{KBN}-$ Figure 1e) and nucleus with notches $(\mathrm{NN}-$ Figure 1f). The incidences of each of these abnormalities are detailed in Table 1 . The $\mathrm{MN}$ incidences ranged from 0 to 8 in 1000 analyzed cells, and represented least when compared with $\mathrm{BN}$ and $\mathrm{LN}$ abnormalities. $\mathrm{MN}$ was recorded $92 \%, 33 \%$ and $66 \%$ of the frogs examined in site 1 to 3 respectively, however, the frequency of MN erythrocytes does not show significant differences between sites $\left(\chi^{2}(2)=2.42, \mathrm{p}=0.298\right)$. Among the remaining four nuclear abnormalities, the $\mathrm{BN}$ are found in all frogs collected from all sites. In site 1 , all abnormalities are 
prominently recorded. Notched nucleus and $\mathrm{BN}$ are recorded in all frogs of site. However, statistically significant dissimilarity in frequency of erythrocytes having $\mathrm{BN}\left(\left(\chi^{2}(2)=19.586, \mathrm{p}=0.0001\right), \mathrm{LN}\left(\left(\chi^{2}(2)=16.38, \mathrm{p}\right.\right.\right.$ $=0.0001), \operatorname{KSN}\left(\left(\chi^{2}(2)=14.983, \mathrm{p}=0.001\right)\right.$ and $\mathrm{NN}\left(\left(\chi^{2}\right.\right.$ $(2)=16.21, \mathrm{p}=0.0001)$ was recorded from the frog collected from the three sites.

The MN test is considered as a fast and powerful tool to assess ecological risk of chemical contaminants $[20,22,23]$. The frog E. cyanophlyctis is a common aquatic inhabitant of all agriculture fields in Western Ghats. Its continuous presence in habitat even after continuous applications of agro-chemicals indicates its low level of sensitivity. However, presence of nuclear abnormality in erythrocyte may indicate that these frogs are also affected by agriculture contaminations. The agrochemical applications in most of part of the world is considered as one of the major contributors of amphibian population decline $[1,26]$. In the present study, we recorded maximum nuclear abnormality in frogs collected from agro-chemical contaminated sites (site 1), which could be linked to the influence of agro-chemicals induced changes. Although the reason and mechanism for appearance of blebbed, lobed, kidney shaped and notched nucleus are not clear, the presence of MN could indicate the genotoxic effect of agro-chemicals. Pesticides $\lambda$-cyhalothrin [17] and cypermethrin [18] are known to induce micronucleus and nuclear shape abnormalities. Hence high incidences of MN observed among the frogs of site 1 may be due to genotoxicity induced by continuous exposure of frogs to agro-chemicals. However, further examination may help to establish probable mechanism. In our study, we recorded considerable differences in appearance of $\mathrm{MN}$ and also other nuclear abnormalities (Table 1). The MN frequencies are known to vary based on season, exposure and types of chemical pollutant [23]. Hegde [25] found 0.15 $-0.45 \mathrm{ppm}$ of total residues of pesticides per kg dry weight of soil in site 1 . Since the site 1 showed a clear presence of residues of pesticides in water and soil, the differences in nuclear abnormalities as recorded in the present study could be also the result of influence of local chemical contaminations.

\section{CONCLUSION}

The appearance of nuclear abnormalities is linked to continuous exposure of frogs to agro-chemical residues in habitat soil and water. In the present study, high incidences of nuclear abnormalities in RBC of frogs $(E$. cyanophlyctis) could be attributed to agrochemical con- tamination. The presence of these abnormalities could aggravate in future and contributes reproductive and behavioural changes in frogs.

\section{ACKNOWLEDGMENT}

Authors are thankful to Department of Environmental Science, Kuvempu University for providing permission and facilities to conduct this experiment. Authors are also thankful to farmers in study sites 1 and local authorities of state fisheries for rendering help during our field studies.

\section{REFERENCES}

1. Mann RM, Hyle RV, Choung CB, Wilson SP (2009) Amphibians and agricultural chemicals: Review of the risks in a complex environment. Environmental Pollution 157 (11): 2903 - 2927. doi: 10.1016/j.envpol.2009.05.015.

2. Ismail M, Khan QM, Ali R et al. (2014) Evaluation of the genotoxicity of chlorpyrifos in common indus valley toad, Bufo stomaticus using alkaline single-cell gel electrophoresis (comet) assay. Agricultural Science 5: 376 - 382. doi: 10.4236/as.2014.54039.

3. Lips KR (1998) Decline of a tropical montane amphibian fauna. Conservation Biology 12 (1): 106 - 112.

4. Venturino A, Rosenbaum E, Decastro AC et al. (2003) Biomarkers of effects in toads and frogs. Biomarker $8(3-4)$ : 167 - 186. doi: 10.1080/1354700031000120116.

5. Falfushinska HI, Romanchuk LD, Stolyar OB (2008) Different responses of biochemical markers in Frogs (Rana ridibunda) from urban and rural wetlands to the effect of carbamate fungicide. Comparative Biochemistry and Physiology Part C: Toxicology and Pharmacology 48 (3): 223 - 229. doi: 10.1016/j.cbpc.2008.05.018.

6. Sewell D, Griffiths RA (2009) Can a single Amphibian species be a good biodiversity indicator? Diversity 1 (2): $102-$ 117. doi:10.3390/d1020102.

7. Leiva-Presa A, Mortensen AS, Arukwe A, Jenssen BM (2006) Altered hepatic Retinol and CYP26 levels in adult European common frogs (Rana temporaria) exposed to p, p'- DDE. Marine Environmental Research 62 (Supplement 1): 510 515. doi: 10.1016/j.marenvres.2006.04.013.

8. Krishnamurthy SV (2003) Amphibian assemblages in undisturbed and disturbed areas of Kudremukh National Park, Central Western Ghats, India. Environmental Conservation 30 (3): 274 - 282. doi: 10.1017/S0376892903000274.

9. Naniwadekar R, Vasudevan K (2007) Patterns in diversity of anurans along an elevational gradient in the Western Ghats, South India. Journal of Biogeography 34 (5): $842-853$. doi: 10.1111/j.1365-2699.2006.01648.x.

10. Vasanthi K, Chairman K, Singh AJAR, Raj AJK (2014) Am- 
phibian diversity and distribution in Courtallam, South Western Ghats foothills, India. International Journal of Biodiversity Conservation 6 (4): $351 \quad-\quad 362$. doi: 10.5897/IJBC2013.0675.

11. Gurushankara HP, Krishnamurthy SV, Vasudev V (2007) Morphological abnormalities in natural populations of common frogs inhabiting agro-ecosystems of central Western Ghats. Applied Herpetology 4: 39 - 45. doi: 10.1163/157075407779766651.

12. Krishnamurthy SV, Meenakumari D, Gurushankara HP, Vasudev V (2008) Nitrate induced morphological anomalies in the tadpoles of Nyctibatrachus major and Fejervarya limnocharis (Anura: Ranidae). Turkish Journal of Zoology 32: $239-244$.

13. Patel AM, Kulkarni PA, Girish KG et al. (2008) Fejervarya limnocharis Morphology. Herpetological Review 31 (9): 77.

14. Vasudev V, Krishnamurthy SV, Gurushankara HP (2008) Organophosphate pesticides-a major threat to anuran populations in an agro ecosystems of Western Ghats, India. Frog$\log$ 83: 8-9

15. Hegde G, Krishnamurthy SV (2014) Analysis of health status of the frog Fejervarya limnocharis (Anura: Ranidae) living in rice paddy fields of Western Ghats, using body condition factors and AchE content. Ecotoxicology and Environmental Contamination 9 (1): 69-76. doi: 10.5132/eec.2014.01.009.

16. Gurushankara HP (2007) Cytogenetical and biochemical effects of organophosphate pesticides malathion and parathion on Rana (Limnonectus) Limnocharis. Ph.D Thesis. Kuvempu University.

17. Muranli FDG, Guner U (2011) Induction of micronuclei and nuclear abnormalities in erythrocytes of mosquito fish (Gambusia affinis) following exposure to the pyrethroid insecticide $\lambda$-cyhalothrin. Mutation Research/Genetic Toxicology and Environmental Mutagenesis 726 (2): 104 - 108. doi: 10.1016/j.mrgentox.2011.05.004.

18. Muranli FDG (2013) Genotoxic and cytotoxic evaluation of pyrethroid insecticides $\lambda$-cyhalothrin and $\alpha$-cypermethrin on human blood lymphocyte culture. Bulletin of Environmental Contamination and Toxicology 90: 357 - 363. doi: 10.1007/s00128-012-0909-z.
19. Venturino A, Pechen De Angelo AM (2005) Biochemical targets of xenobiotics: Biomarkers in amphibian ecotoxicology. Applied Herpetology 2: 335 - 353. doi: 10.1163/1570754054507433.

20. Josende ME, Tozetti AM, Alalan MT et al. (2015) Genotoxic evaluation in two amphibian species from Brazilian subtropical wetlands. Ecological Indicators 49: 83 - 87.

21. Mouchet F, Gauthier L, Mailhes C et al. (2006) Comparative evaluation of genotoxicity of Captan in amphibian larvae (Xenopus laevis and pleurodeles walt') using the comet assay and the micronucleus test. Environmental Toxicology 21 (3): 264 - 277. doi: 10.1002/tox.20180.

22. Ferrier V, Gauthier L, Zoll-Morreux CL, Haridon J (1998) Genotoxicity testing in amphibians: a review. In: Microscale testing in aquatic toxicology: Advance techniques and Practice. Philadelphia, CRC Press, pp $507-519$.

23. Da Rocha CAM (2011) The micronucleus test in erythrocytes of amphibian larvae as tool for xenobiotic exposure site assessment: A brief review and an example using Lithobates catesbeianus exposed to copper sulphate. Middle-East Journal of Scientific Research 8 (1): 23 - 29.

24. Amphibia Web (2017) Amphibian. http://amphibiaweb.org/. Accessed: July 2017.

25. Hegde G (2014) Use of agrochemicals and their influence on population structure of Anuran amphibians in agro-ecosystems of Western Ghats. Ph.D Thesis. Kuvempu University.

26. Lajmanovich RC, Cabagna M, Peltzer PM et al. (2005) Micronucleus induction in erythrocytes of the Hyla pulchela tadpoles (Amphibia: Hylidae) exposed to the insecticide endosulfan. Mutation Research/Genetic Toxicology and Environmental Mutagenesis $587(1-2): 67$ - 72. doi: 10.1016/j.mrgentox.2005.08.001.

27. Carrasco KR, Tilbury TL, Myers MS (1990) Assessment of piscine micronuclei test as an in situ biological indicator of chemical contaminant effects. Canadian Journal of Fisheries and Aquatic Sciences 47 (11): 2123 - 2136. doi: 10.1139/f90237.

28. Strunjak-Perovic IR, Coz-Rakovac, Topicpopovic N, Jadan M (2009) Seasonality of nuclear abnormalities in gilthead sea bream Sparus aurata (L) erythrocytes. Fish Physiology and Biochemistry 35 (2): 287 - 291. doi: 10.1007/s10695-0089208-3. 